\title{
Holocene land-sea climatic links on the equatorial Pacific coast (Bay of Guayaquil, Ecuador)
}

\begin{tabular}{|c|c|}
\hline Journal: & The Holocene \\
\hline Manuscript ID: & HOL-15-0112.R1 \\
\hline Manuscript Type: & Paper \\
\hline Date Submitted by the Author: & 02-Sep-2015 \\
\hline Complete List of Authors: & $\begin{array}{l}\text { Seilles, Brice; Ecole Pratique des Hautes Etudes, UMR } 5805 \text { CNRS EPOC } \\
\text { Sanchez Goñi, Maria Fernanda; Ecole Pratique des Hautes Etudes, UMR } \\
5805 \text { CNRS EPOC } \\
\text { Ledru, Marie-Pierre; IRD, UMR 226, Institut des Sciences de I'Evolution de } \\
\text { Montpellier (ISEM) (UM2 CNRS IRD) } \\
\text { Urrego, Dunia; University of Exeter, College of Life \& Environmental } \\
\text { Sciences } \\
\text { Martinez, Philippe; University of Bordeaux, UMR } 5805 \text { CNRS EPOC } \\
\text { Hanquiez, Vincent; University of Bordeaux, UMR } 5805 \text { CNRS EPOC } \\
\text { Schneider, Ralph; University of Kiel, Institute of Geosciences }\end{array}$ \\
\hline Keywords: & $\begin{array}{l}\text { ITCZ, Humboldt Current, ENSO, Ecuadorian western Cordillera, Pacific SST, } \\
\text { Holocene }\end{array}$ \\
\hline Abstract: & $\begin{array}{l}\text { We analyzed the pollen content of a marine core located near the bay of } \\
\text { Guayaquil in Ecuador to document the link between sea surface } \\
\text { temperatures (SST) and changes in rainfall regimes on the adjacent } \\
\text { continent during the Holocene. Based on the expansion/regression of five } \\
\text { vegetation types, we observe three successive climatic patterns. In the } \\
\text { first phase, between } 11,700 \text { and } 7700 \text { cal yr BP, the presence of a cloud } \\
\text { (Andean) forest in the mid altitudes and mangroves in the estuary of the } \\
\text { Guayas Basin, were associated with a maximum in boreal summer } \\
\text { insolation, a northernmost position of the Intertropical Convergence Zone } \\
\text { (ITCZ), a land- sea thermal contrast, and dryness. Between } 7700 \text { and } 2850 \\
\text { cal yr BP, the expansion of the coastal herbs and the regression of the } \\
\text { mangrove indicate a drier climate with weak ITCZ and low ENSO variability } \\
\text { while austral winter insolation gradually increased. The interval between } \\
4200 \text { and } 2850 \text { cal yr BP was marked by the coolest and driest climatic } \\
\text { conditions of the Holocene due to the weak influence of the ITCZ and a } \\
\text { strengthening of the Humboldt Current. After } 2850 \text { cal yr BP, high } \\
\text { variability and amplitude of the Andean forest changes occurred when } \\
\text { ENSO frequency and amplitude increased, indicating high variability in } \\
\text { land-sea connections. The ITCZ reached the latitude of Guayaquil only } \\
\text { after } 2500 \text { cal yr BP inducing the bimodal precipitation regime we observe } \\
\text { today. Our study shows that besides insolation, the ITCZ position and } \\
\text { ENSO frequency, changes in eastern equatorial Pacific SSTs play a major } \\
\text { role in determining the composition of the ecosystems and the hydrological } \\
\text { cycle of the Ecuadorian Pacific coast and the Western Cordillera in Ecuador. }\end{array}$ \\
\hline
\end{tabular}




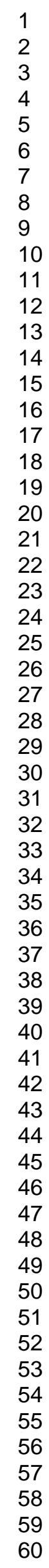

SCHOLARONE $^{\text {IM }}$

Manuscripts

http://mc.manuscriptcentral.com/holocene 


\section{HOLOCENE}

5

9

8

9

BO

11
$\uparrow 2$

13

14

15

16

七7

18

阝9

20

21

22

23

24

25

126

36

137 38

Holocene land-sea climatic links on the equatorial Pacific coast (Bay of Guayaquil, Ecuador)

Brice Seillès ${ }^{1}$, Maria Fernanda Sánchez Goñi ${ }^{1}$, Marie Pierre Ledru ${ }^{2}$, Dunia H. Urrego ${ }^{1,3}$, Philippe Martinez ${ }^{4}$, Vincent Hanquiez ${ }^{4}$ and Ralph Schneider ${ }^{5}$

1. Ecole Pratique des Hautes Etudes (EPHE), UMR-CNRS 5805 EPOC, University of Bordeaux, Allée Geoffroy St Hilaire, 33615 Pessac, France, mf.sanchezgoni@epoc.u-bordeaux1.fr

2. IRD, UMR 226, Institut des Sciences de I'Evolution de Montpellier (ISEM) (UMZ CNRS IRD EPHE), Place Eugène Bataillon cc 061, 34095 Montpellier Cedex, France, marie-pierre.ledru@ird.fr

3. College of Life \& Environmental Sciences, University of Exeter, Amory Building B302, Rennes Drive, EX4 4RJ, Exeter, UK, D.Urrego@exeter.ac.uk

Field Code Changed

4. University of Bordeaux, UMR CNRS 5805 EPOC, Allée Geoffroy St Hilaire, 33615 Pessac, France, p.martinez@epoc.u-bordeaux1.fr

Field Code Changed 5. Institute of Geosciences, University of Kiel, Ludewig-Meyn-Str. 10, 24118 Kiel, Germany, schneider@gpi.uni-kiel.de 


\section{HOLOCENE}

1

2

3

4

5

29

30

9

310

11

322

33

14

345

16

357 18

$3 \% 9$

20

\section{Abstract}

We analyzed the pollen content of a marine core located near the bay of Guayaquil in Ecuador to document the link between sea surface temperatures (SST) and changes in rainfall regimes on the adjacent continent during the Holocene. Based on the expansion/regression of five vegetation types, we observe three successive climatic patterns. In the first phase, between 11,700 and 7700 cal yr BP, the presence of a cloud (Andean) forest in the mid altitudes and mangroves in the estuary of the Guayas Basin, were associated with a maximum in boreal summer insolation, a northernmost position of the Intertropical Convergence Zone (ITCZ), a land- sea thermal contrast ${ }_{2}$ and dryness. Between 7700 and $2850 \mathrm{cal}$ yr BP, the expansion of the coastal herbs and the regression of the mangrove indicate a drier climate with no-weak ITCZ and low ENSO variability while austral winter insolation gradually increased. The interval between 4200 and 2850 cal yr BP was marked by the coolest and driest climatic conditions of the Holocene due to the absence of ITCZ weak influence of the ITCZ and a strengthening of the Humboldt Current. After 2850 cal yr BP, high variability and amplitude of the Andean forest changes occurred when ENSO frequency and amplitude increased, indicating high variability in land-sea connections. The ITCZ reached the latitude of Guayaquil only after 2500 cal yr BP inducing the bimodal precipitation regime we observe today. Our study shows that besides insolation, the ITCZ position and ENSO frequency, changes in eastern equatorial Pacific SSTs play a major role in determining the composition of the ecosystems and the hydrological cycle of the Ecuadorian Pacific coast and the western CordilleraWestern Cordillera in Ecuador.

key words : ITCZ, Humboldt Current, ENSO, Ecuador ${ }_{2}$ ian Western Cordillera, Pacific SST, Holocene 


\section{HOLOCENE}

\section{1 - Introduction}

The equatorial Eastern Pacific coast represents one of the largest desertie areas of the planet. This desert stops abruptly on the Peruvian-Equatorial margin, between $1^{\circ}$ and $3^{\circ} \mathrm{S}$ latitude, where within a few kilometers of distance, it is suddenly replaced by a luxuriant and diverse tropical rainforest (Barthlott‡ et al., 2005). This contrasted biogeographical pattern is created by the boundary effect of the position of the Intertropical Convergence Zone (ITCZ) from the north, and by the intensity of the cold Humboldt Current from the south (Jorgensen and LeonYanez 1999). The interplay between the northern and the pole-equator southern hemisphere seasonal insolation and pole-equator temperature gradient controls the position and amplitude of the ITCZ, oscillating between $10^{\circ} \mathrm{N}$ and $3^{\circ} \mathrm{S}$, and the characteristic bimodal regional rainfall distribution of the tropics (Garreaud et al..,2009). Today, the cooling of surface waters in the southeastern equatorial Pacific during the austral winter, displaces the SST maximum (and thus the zone of convergence) into the Northern Hemisphere, and inversely during the austral summer. Superimposed to this ocean-atmospheric coupling ${ }_{\iota}$ the climate is regularly submitted to the interannual variability of the El Niño Southern Ooscillation (ENSO) (Vuille et al., 2000 ${ }_{\bar{i} \overline{ }}$ Garreaud et al., 2009 $9_{\overline{i^{\prime}}}$ Schneider et al., 2014). On the equatorial eastern-Eastern equatoriatPacific, ENSO is characterized by an abrupt change in Sea Surface Temperature (SST) that affects the amplitude of the seasonal shifts of the ITCZ or the location of the northernmost limit of influence of the Humboldt Current that will control the hydrological cycle on the continent (Leduc et al., 2009; Garreaud et al. 2009).

Seasonal shifts of the ITCZ during the Holocene are well documented on the northern coast of Venezuela (Haug et al..2 2001). The seasonally varved marine record of Cariaco off the coast of Venezuela shows the Holocene wettest period between 10,500 and $5400 \mathrm{cal}$ yr BP, a period called the Holocene $\underline{T}$ thermal $\underline{\text { Mmaximum }}$ and is related to a more northerly position of the ITCZ. This moist period is followed by large century-scale variations in precipitation between 3800 and $2800 \mathrm{cal}$ yr BP explained by increased frequency of ENSO events. Marine and terrestrial records off the Peruvian and Ecuadtorian margin reveal that the ITCZ position also varied trough time (Cane et al., 2005), and the hydroclimate was in anti-phase with that of the Cariaco basin (Mollier-Vogel et al., 2013). Superimposed to this long-term hydroclimate variability, millennial-scale ENSO events in the southern and northern tropics punctuated the Holocene. The frequency of these events increased from 7000 to 1000 cal yr BP, with a 2 to 7-year cyclicity since 5000 cal yr BP (Moy et al., 2002). The maximum of ENSO frequency was reached between 3500 and 2600 cal yr BP (Haug et al., 2001; Riedinger et al., 2002), possibly in response to a threshold reached by the gradual decrease in 
boreal summer insolation (Rodbell et al., 1999; Clement et al., 2000), and leading to the observed marked aridity/humid trends period at Cariaco/Guayas. Recent climate simulations showed that insolation is the major driver of SST changes in the equatorial Eeastern Pacific and has a greater effect on seasonality and interannual variability since the beginning of the Holocene (Braconnot et al..2012).

However, the processes and degree of coupling and processes-between, on the one hand, equatorial Eeastern Pacific SST rainfall distribution and intensity on land and, on the other hand, insolation forcing, ITCZ position and ENSO variability, are far from being understood. Here, we address this issue by presenting the first continuous marine pollen record of the equatorial Eeastern Pacific tropicatmargin and use the related changes in vegetation and SST to characterize the boundaries of the ITCZ and the Humboldt Current during the Holocene. This direct comparison between terrestrial and oceanic climatic tracers is an original approach for this complex region.

\section{Present-day Environmentalenvironmental setting}

\section{1 - Climate and oceanic circulation}

The climate of the Guayaquil region is controlled by seasonal shifts of the ITCZ. The rainfall distribution shows a bimodal with a 4-month rainy season (JFMA) when the ITCZ is located at the latitude of Guayaquil and a long dry season (JJASON) when the ITCZ is located further north at the equator (climate diagram in Fig. 1). Consequently today the maxima in precipitation and river discharge in the Guayaquil basin and Cordillera mid-elevation is observed during the austral summer (Rincón-Martínez et al., 2010). Further south, the rainfall distribution of the Pacific coast and of the western Andean Cordillera, from southern Perú until the latitude of Guayaquil, is under the influence of the Humboldt current, a cold current that provokes an upwelling along the western margin of the South American continent, maintaining a long line of coastal desert (Vuille et al., 2000; Buytartater 2006). Aridity is found along the path of the cold Humboldt Current, which stabilizes the atmosphere under high pressures. The desert stops exactly-south of Guayaquil where the Humboldt Current is deviated to the west.

Figure 1 


\section{HOLOCENE}

Anomalies in the seasonal pattern of rainfall distribution are observed during the ENSO, when the temperature gradient between the eastern Eastern and Whestern Pacific is modified. This interannual variability shows two phases (Wyrtki, 1975; Markgraf and Diaz 2000): La Niña (cold) phase is characterized by SST decrease in the equatorial Eeastern Pacific margin and drier climate on the continent; during the El Niño (warm) phase of the oscillation, the sea current is reversed leading to wind decrease in the eastern-equatorial Eastern tropical-Pacific and warm water along the Peruvian margin and more precipitation on the continent. tropical Pacific is therefore related to precipitation increase in this region._ENSO is therefore the main cause of present-day climatic variability of these regions at the edge of the tropical Pacific Ocean (Tudhope et al., 2001; Moy et al., 2002). Additionally, previous results show that ENSO variability at multi-decadal scale is more important for long-term climate characterization than considering the interannual variability (or number of El Niño La Niña events / year ) (Morales et al., 2012, Ledru et al., 2013).

\section{2 - Present-day vegetation and its pollen representation}

As the bay of Guayaquil is situated in a transitional zone generated by the interplay between the cold Humboldt Current and the Equatorial warm current, the distribution of the ecosystems is divided into two main types: a desertic vegetation cover in the South south and a wet tropical ecosystem forests with mangrove swamps in the Northnorth of the study area. Within the basin of Guayaquil the distribution of the vegetation is subdivided into five main ecosystems (pie chart in Fig. 1, Table I). Their respective pollen indicator taxa have been grouped according to published pollen-vegetation calibration datasets (Urrego et al. 2011; Ledru et al 2013) and list of plants (Jorgensen and Leon-Yanez 1999) with:

1. The Andean forest refers to the evergreen and ombrophilous forests up to a mean elevation of $3600 \mathrm{~m}$. This

Formatted: Space After: $0 \mathrm{pt}$ vegetation is essentially represented by Podocarpus, Alnus, Morella (Myrica) and Myrsine, and associated with warm cool and relatively wet environmental conditions all year round. Alnus occurs on wet soils along rivers in this

Formatted: Font: Italic montane forest but can also occur as swamp forest (carr) around water bodies (Marchant et al., 2002). Modern studies on the pollen representation of the Eeastern Cordillerawestern CordilleraEastern Cordillera vegetation (Urrego et al., 2011) show that Hedyosmum is also a frequent component of this forest between 1500 and $3000 \mathrm{~m}$ asl, although it also occurs in the Pacific forest. 


\section{HOLOCENE}

5
2. The Pacific rainforest is composed of evergreen and semi-deciduous species and distributed between the coastal piedmont in the periphery of the mangrove swamp and the Western Cordillera. This forest is essentially represented by Urticaceae/Moraceae-type, and directly affected by the evolution-development (expansions and fcontractions) of the mangrove forest.

3. The Coastal herbs group is composed of desert shrubs and herbs and essentially represented by

Chenopodiaceae/Amaranthaceae, Acalypha and Ambrosia peruana that develop under cold and dry conditions.

4. The Páramos or high-elevation tropical grasslands are located above treelinethe upper forest line and are

represented by Acaena-Polylepis-type and Asteraceae-Baccharis-type that groups all the Asteraceae tubuliflorae excluding Ambrosia-type, and Acaena-Polylepis-type:

5. The mangrove swampforest, essentially represented by Rhizophora corresponds to coastal vegetation related to a wet and salty-saline environment in the tropical and subtropical regions dominated by the Equatorialequatorial warm current. It is impacted by the marine dynamics (sea level, tidal system, salinity) but also by hydric and nutrient contributions of the riverine runoff.

Pollen grains from these main vegetation types are mostly transported by the Guayas River as previous works (e.g. Heusser and Balsam, 1977) clearly show that cores located close to river mouth recruit preferentially pollen via fluvial transport. This is particularly true for this region where the dominant winds come from the ocean. Once in the sea, planktonic filter feeder organisms consume sinking debris, (including pollen grains) and produce feacal pellets which have a greater sinking velocity in the water column, (Hooghiemstra et al., 2006).

Table I

\section{3-Material and methods}

\section{1- The marine sedimentary sequence}

A piston core of $1,062 \mathrm{~cm}$ length (-M772-056 $f^{\circ} 44,99^{\prime} \mathrm{S}, 81^{\circ} 07,25^{\prime} \mathrm{W}$, and $350 \mathrm{~m}$ water depth) was drilled in 2008 in the southern part of the Bay of Guayaquil (Mollier-Vogel et al., 2013). This region is characterized by a sedimentary platform, the biggest sedimentary basin of the Andes, and the largest drainage system in western Ecuador (Stevenson, 1981), with an outer shelf break into the continental margin located at a water depth of $\sim 100 \mathrm{~m}$

Formatted: Font: $11 \mathrm{pt}$
Formatted: Font: $11 \mathrm{pt}$, Not Highlight
Formatted: Font: $11 \mathrm{pt}$
Formatted: Font: $11 \mathrm{pt}$, Italic
Formatted: Font: $11 \mathrm{pt}$
Formatted: Font: $11 \mathrm{pt}$

Formatted: Indent: First line: $0.49 "$, Space After: $10 \mathrm{pt}$, Line spacing: Double

Formatted: Not Highlight

Formatted: Font: +Body (Calibri), $11 \mathrm{pt}$

Formatted: Font: +Body (Calibri), 11 pt, English (U.S.)

Formatted: Font: +Body (Calibri), $11 \mathrm{pt}$

Formatted: Font: +Body (Calibri), 11 pt, English (U.S.)

Formatted: Font: +Body (Calibri), 11 pt

Formatted: Font: +Body (Calibri), 11 pt, English (U.S.)

Formatted: Font: +Body (Calibri), 11 pt

Formatted: Font: +Body (Calibri), 11 pt, English (U.S.)

Formatted: Indent: First line: 0.49 " 
(Witt and Bourgois, 2010). It is the outcome ofThis platform, which begins on the island of Puna and extends up to

Formatted: Font: $11 \mathrm{pt}$ $100 \mathrm{~km}$ into the Ecuadorian inland and up to an elevation of more than $6000 \mathrm{~m}$, resulted from a major subsidence phenomenon combined with an important sedimentary load of fluviomarine alluvia sediments from the estuary of the river Guayas, which gegins on the istand of Puna and extends up to $100 \mathrm{~km}$ into the Ecuadorian inland and up to an elevation of more than $6000 \mathrm{~m}$. Today the sediments at the coring site are dominated by siliciclastic material, and secondarily they contain marine biogenic carbonates (Mollier-Vogel et al., 2013). Sedimentary discharge into the Gulf of Guayaquil is mainly linked to the Guayas River runoff, which integrates rainfall from a catchment located North north of Guayaquil on the western flank of the Ecuadorian Andes (Twilley et al., 2001). The catchment area of this river drains the $32.674 \mathrm{~km}^{2}$ (Fig. 1) of the Guayaquil basin that represents $64 \%$ of the total drainage sediments (Rincón-Martínez et al., 2010). The Guayas River discharge closely tracks the integrated precipitation and snow melting from tand to-the basin catchment without any time lag (Twilley et al., 2001).

\subsection{1- Chronology}

The chronology of core M772-056 is based on 11 radiocarbon measurements on the planktonic foraminifera Neogloboquadrina dutertrei performed at the Leibniz Laboratory for Radiometric Dating and Stable Isotope Research, Kiel University (Mollier-Vogel et al., 2013) (Table II). Ages ${ }^{14} \mathrm{C}$ ages were converted into calendar ages using the CALIB 6.0 program (Stuiver and Reimer, 1993). Radiocarbon ages were first corrected using MARINE09 (Reimer et al., 2009), with a constant R of $200+/-50$ years based on sites with known reservoir ages situated closest to our core location in the marine reservoir correction database (http://calib.qub.ac.uk/marine/). The age model was established by linear interpolation (Mollier-Vogel et al., 2013).

Table II

\subsection{2- Micropaleontological analyses}

One hundred twenty-five silty-clay samples (between 4 and $-10 \mathrm{~cm}^{3}$ ) were taken at $10 \mathrm{~cm}$ intervals except for the upper $80 \mathrm{~cm}$ that covers the last millennium, where the sampling resolution was $5 \mathrm{~cm}$. Pollen preparation follows the 52

Formatted: Not Highlight

Formatted: Font: $11 \mathrm{pt}$
Field Code Changed

Field Code Changed treatment (cold $10 \%, 25 \%$ and $50 \% \mathrm{HCl}$, cold $45 \%$ and $70 \% \mathrm{HF}$ and then $\mathrm{KOH}$ ), the samples were sieved through a 5 
$\mu \mathrm{m}$ nylon mesh to concentrate the palynomorphs in the final residue. Two Lycopodium tablets with known concentration were added to each sample to calculate the pollen and spore concentrations. The final residue for pollen analysis was mounted unstained in bidistilled glycerine. Pollen grains were counted using a Zeiss Axioscope light microscope at $\times 400$ and $\times 1000$ (oil immersion) magnification. The identification of the different palynomorphs was based on a recent pollen reference collection held at the Institute of Evolutionary Science at the University of Montpellier-z, and on published morphological descriptions (Hooghiemstra, 1984; Roubik and Moreno 1991). In most of the 125 samples analyzed, we counted more than 125 pollen grains-excluding spores, and between 25-40 morphotypes including herbs, shrubs and trees. The pollen percentages for terrestrial taxa are based on a main pollen sum which excludes spores, aquatics, unidentifiable (corroded, broken, crumpled) and unknowns. The percentages for fern spores, aquatics, unidentifiable and unknowns are based on the -total sum that corresponds to all the counted pollen grains and the main pollen sum plus fern spores, aquatics, :identified, aquatic, unidentifiable

\section{4-Results and interpretation}

4.1- Long-term vegetation and climate changes in the Guayaquil basin during the Holocene

The chronology of core M772 056-5 encompasses the very end of the Late Gglacial and the entire Holocene, from 12,300 cal $-y r$ BP to the present. The sedimentation rate is relatively constant varying between $\sim 63$ and $117 \mathrm{~cm}$ 
$\mathrm{kyr}^{-1}$. The temporal resolution of the pollen analysis is one century on average escillating ranging between 170 and 48 years. The last millennium has the finest resolution, i.e. 60 years in averageseral decades.

The interpretation of the pollen diagram was assisted by the analysis of the top core sample, taken at $3.5 \mathrm{~cm}$ core depth, that shows the pollen representation of the vegetation of the Guayaquil basin during the last decade (Fig. 1). We observed that the pollen assemblage is mainly composed of arboreal pollen, including $60.8 \%$ of Andean forest (7.2 \% of Alnus) and 1.3-\% of Pacific rainforest, 19-\% of mangrove, 3.9-\% of Páramo and $16.3 \%$ of coastal herbs. These pollen percentages respect reflect the pollen production and proportion of the surface occupied by the five main vegetation communities of the Guayaquil basin and the efficiency of pollen transport to the ocean floor (Figure 1).

Therefore, we consider that changes in the pollen record accuratelyrepresents an integrated image of the vegetation dynamics in the Guayaquil basin during the Holocene (Fig. 2), and therefore-hence of the regional climate, as previously observed for other world regions (Heusser, 1985; Dupont, 2003: Hooghiemstra et al., 2006). The cluster analysis performed on the total pollen-counts show two major clusters that are in turn sub divided into two and three zones, respectively (Figure 2).

Figure 2

In t The first cluster, 12,300-7700 cal yr BP, is divided intowe recognize two zones. The first zone, between 12,300 and Formatted: Font: $11 \mathrm{pt}$ $10,000 \mathrm{cal}$ yr BP, is characterized by the progressive increase and full development of the mangrove (Rhizophora) and Andean forest (Alnus, Podocarpus, Myrica, Myrsine) while the coastal herbs-vegetation (Chenopodiaceae-type, Acalypha and Ambrosia-type) frequencies-progressively decrease. In the second zone, $10,000-7700$ cal yr BP, the mangrove started to decrease $-\dot{-}$ the Andean forest shows a maximum and while a reduction of the coastal vegetation relatively low frequencies of the coastal herbs are is observed. Warmer and wetter conditions are revealed by this Formatted: Not Highlight first cluster.

In tThe second cluster, from 7700 until the present, is divided intothree zones, can be recognized.- The first zone from 7700 to $4200 \mathrm{cal}$ yr BP is characterized by a substantial increase of Alnus frequencieswoodlands, the maximum frequency proportion of Podocarpus and a slow decrease in mangrove swamps reflecting relatively warm climate and the wettest conditions frequencies. However, $t$ The strong expansion high frequencies-of Podocarpus, Alnus, Myrica Morella and fern spores in the Andean forest group is followed by their progressively decrease during this zonetime 
interval while the coastal herbs-vegetation (Chenopodiaceae-type, Acalypha and Ambrosia-type) increaseexpands.

The mangrove frequencies-forest shows low and high stands with a maximum frequencies-development at $6000 \mathrm{cal}$ yr BP and two minima at $7500 \mathrm{cal} \mathrm{yr} \mathrm{BP}$ and at $5600 \mathrm{cal} \mathrm{yr} \mathrm{BP.} \mathrm{Maximum} \mathrm{warmth} \mathrm{and} \mathrm{humidity} \mathrm{conditions} \mathrm{reverse}$ during this zone as reflected by the long-term substantial decrease of the Andean and mangrove forests. The second zone, between 4200 and $2850 \mathrm{cal}$ yr BP, is characterized by the maximum frequencies-expansion of the-coastal svegetation, Andean forest taxa (Podocarpus, AyricaMorella, Myrsine) and the lowest frequency proportion of the mangrove taxa. This zone reveals the driest conditions in the Guayas basin. The third zone, from $2850 \mathrm{cal}$ yr BP to the present day, is a period characterized by a slight decrease but still high Páramo (Asteraceae-Baccharis-type, Polylepis/Acaena-Polylepis-type) and coastal herb frequenciesvegetation (Chenopodiaceae-type, Acalypha and Ambrosia-type), and the increase of Alnus and mangrove-frequencies. An alternation of increases and decreases in the Andean forest cover escillates-is inferred between 2850 and 850 cal yr BP. This trend reverses with an increase of Andean forest from $850 \mathrm{cal}$ yr BP up to the present at the expenses of both the Páramo and the coastal herbs. A wet trend characterizes this time period.

Our marine pollen sequence record M772056-5 was compared with the closest terrestrial pollen record, i.e. the Surucucho pollen sequence (Fig. 3) located in the Guayaquil basin at more than $3000 \mathrm{~m}$ asl (Colinvaux et al., 1997; Weng et al., 2004). Both marine and terrestrial pollen sequences show similar fluctuations in the evolution development of the Alnus forest. As already shown by the pollen analysis of the top-most core sample, the marine sequence accurately-records not only the coastal vegetation but also the vegetation occupying the river basin further inland and up to high altitudes $(3600 \mathrm{~m})$. Andean alders Alders reach their maximum expansion from $8000 \mathrm{cal}$ yr BP to the present, indicating warm and moist conditions at high altitudes, except between 4200 and 2850 cal yr BP when Alnus groves-woodlands declined synchronously with the Andean forest reduction (Colinvaux et al., 1997; Weng et al., 2004), reflecting the regional driest and coldest period of the Holocene.

Figure 3

4.2- Short-term vegetation and climate changes

Formatted: Not Highlight

Formatted: Font: $11 \mathrm{pt}$

\begin{tabular}{|l|}
\hline Formatted: Not Highlight \\
\hline Formatted: Font: $11 \mathrm{pt}$ \\
\hline Formatted: Not Highlight \\
\hline Formatted: Font: $11 \mathrm{pt}$ \\
\hline Fighlight \\
\hline Formatted: Font: $11 \mathrm{pt}$ \\
\hline Formatted: Not Highlight \\
Formatted: Font: $11 \mathrm{pt}$ \\
\hline Formatted: Not Highlight \\
Formatted: Font: $11 \mathrm{pt}$ \\
\hline Formatted: Not Highlight \\
Formatted: Font: $11 \mathrm{pt}$ \\
\hline Formatted: Not Highlight \\
\hline
\end{tabular}


Superimposed to these long-term trends, our results suggest twenty-nine short-term vegetation escillations-changes from Andean forest to coastal herbs-vegetation and back to forest and inversely-(Fig. 2).

The 3000 -year period between the onset of the Holocene, 11,700 and 7,700 cal yr BP was interrupted by five multicentennial cooling and drying events. These oscillations are inferred from the repeated contractions of the Andean forest: odd pollen subzones M772-1 and M772-3 and even pollen subzones M772-6 to 10 . The first maximum of the Andean forest, M772-5, occurred at around 10,100 cal yr BP, synchronous with the highest values of mangrove. Then, the mangrove contracted contemporaneously with a second maximum of Andean forest between 9700 and 9250 cal yr BP (M772-7). Between 9250 and 9000 cal yr BP, the Andean forest setback was associated with the maximuna values of the Pacific forest (M772-8) (Fig. 2).

A The long-term regional drying trend characterized the second long-term phase-from 7700 to 2850 cal yr BP.This phase was punctuated by three multi-centennial dry events (Andean forest contractions at 16). After the driest period of the Holocene in Guayas, between 4200 and 2850 cal yr BP, the third long-term phase marked by a wetter trend since 2850 cal yr BP was interrupted by two dry intervals respectively at:- $-2400-1950$ cal yr BP and 1600-1400 cal yr BP (zones M772-20-21 and $22 \underline{23}$ ) marked by the reduction of both Andean forest and mangrove and a minima of Podocarpus. The last 1000 years have been analyzed at an increasedhigher resolution (Fig. 2) and despite coarser ${ }^{14} \mathrm{C}$ chronology for this interval, the $\mathrm{M} 772056-5$ record suggests five intervals of tandscape andregional vegetation elimate-changes that indicate an alternation of wetter and drier periods. The $\underline{\text { drier }}$ intervals 1000-750, 450-350, 200-100 cal yr BP (MM772-24, 26 and 28) are characterized withreflected by low or decreasing Andean forest, mangrove swamps and Alnus frequencieswoodlands. The highest valuesmost abundantce presence of Alnus occurred-between 650 and $450 \mathrm{cal} \mathrm{yr} \mathrm{BP}$ and 350 and $200 \mathrm{cal} \mathrm{yr} \mathrm{BP} \mathrm{(MM772-25} \mathrm{and} \mathrm{27)} \mathrm{record}$ $\underline{\text { moisture increase in the Guayas Basin. In the last century, from } 100 \text { cal yr BP to } 33 \text { cal yr BP (M772-29), we observe a }}$ the-simultaneous expansion of the mangrove and of the Andean forest ${ }_{L}$ for the second time after the one observed at the beginning of the Holocene, which relates toindicates a warming trend.

\section{5-Discussion}

\section{1- Related changes in vegetation and sea-surface temperature in the Guayaquil basin}

The interval between 12,000 and 10,000 cal yr BP is characterized by the progressive development of the mangrove and the Andean forest with a maximum at around 10,000 cal yr BP (Fig. 4). Terrigenous input estimated from the 


\section{HOLOCENE}

1

2

3

4

5

298

298

9

$30 p 0$

11

30,12

$302^{3}$

14

$303^{5}$

16

30h7

18

3059

20

3061

उ०ी

23

3084

25

3096

27

3188

29

3130

331

32

3133

34

3135 36 same core (see log Ti/Ca on in figure Fig. 4), show high river discharges at the onset of the Holocene in agreement with the concomitant rapid and strong glacier melting observed in the Cordillera (Mollier-Vogel et al., 2013; Jomelli et al 2011). The progressive decrease in terrigenous input after the early-Holocene peak of glacier melting suggests low precipitation on the continent. On the other hand the increase of Andean forest suggests warming and higher moisture ateslevels. However the concomitant observed low Alnus frequencies-percentages could characterize both cooling in coastal areas and a different moisture regime than that prevailing today with drier edaphic conditions and more cloud dripping. At the same time, SSTs remain low (Mollier-Vogel et al., 2013). Such divergences between coastal and highland temperatures are also observed in modern climate reconstructions with the development of a strong vertical stratification of temperature trends in the atmosphere (Vuille et al., 2015). This specific pattern of vegetation can be explained by the development of a cloud forestformation of fog and cloud condensation on the flanks of the western-Western cordillera-Cordillera enhanced by a high temperature contrast between a cold sea and a warming land at the onset of the interglacial as already noticed by Jomelli et al. (2011).

Figure 4

Between 10,000 and $7700 \mathrm{cal}$ yr BP the cloudandean forest was continuously present-maintained although progressively decreasing. We know from the Atlantic side that the ITCZ was maintained in a northernmost position (Haug et al 2001). In this study, relatively cold SSTs also show the absencea weak ofinfluence of the ITCZ on the Pacific side at lower latitudes making a link with the ITCZ on the Atlantic. The position of the ITCZ to the north of our study area prevented from the installation of a bimodal seasonality that would bring austral summer rainfalls. At Guayas during this time interval, the SST was warmer than during the previous time interval, the land-sea temperature contrast weaker and the cloud formation on the continent less active. The climate became warmer and the continent progressively drier. The development of Alnus overall followed the progressive SST warming (Fig. 4). This land-sea coupling can be related to the progressive increase of austral winter insolation at the latitude of Guayaquil. Between 7700 and $4200 \mathrm{cal}$ yr BP SSTs show maximum values. The vegetation was characterized by a maximum of Alnus and Podocarpus stands while the Andean forest cover continuesto-d to decrease. This opposite trend between Alnus and the rest of the Andean forest was also observed during the last glacial maximum (Mourguiart and Ledru,
Formatted: Font: $11 \mathrm{pt}$

Formatted: Font: $11 \mathrm{pt}$ 
2003). Alnus is a heliophilous species thatand_requires less atmospheric moisture supply than the Andean forest although it benefits from azonal wet soils which may exist even under relatively low precipitation levels.:-

9

3280 11
Mangrove swamps substantially decreased from $7700 \mathrm{cal}$ yr BP, and reached a minimum between 5500 and $\sim 2850$ cal yr BP that could indicate a decrease of SST due to the stronger penetration of the Humboldt Current in the bay or mean La-Niña like conditions as observed in the southern Pacific (Carré et al 2011). However, as the SST reached their highest values during this interval (Fig. 4), the first hypothesis is rejected. Previous studies showed the tight link between fluctuations in the mangrove extent and sea level changes in the Caribbean region (Ellison and Stoddart, 1991; Parkinson et al., 1994). Therefore, mangrove contraction in the bay of Guayaquil seems to respond preferentially to the reduction of marshlands due to a deceleration in sea level risesea leveldeceleration. Between 7700 and 6000 cal yr BP a slight re-expansion of the mangrove coincides with the stabilization of the sea level dated between 7000 and 6000 cal yr BP (Lambeck and Chappell, 2001; Siddall et al, 2003), and the formation of a delta (Stanley and Warne, 1994). The maximum reduction of mangrove stands at $\sim 5000 \mathrm{cal}$ yr BP was also documented in the Panamá basin, and interpreted as the replacement of the mangrove swamp by the lowland forest as the result of the sea level stabilization and the progradation of fluvial sediments (González and $\underline{\text { et }}$ al., 2006). However this second hypothesis does not explain the decrease in precipitation and the contraction of the Andean forest on the continent. Another hypothesis is that the southern shift of the ITCZ did not reach the latitude of Guayas during the austral summer and remained to-at a northern position as shown by the Cariaco record (Haug et al 2001). The SSTs were warm but the summer rainy season was weak or absent as shown by the low terrigenous input in the sediment. According to the study of Haug et al. (2001), the ITCZ started to move south after 5400 cal yr BP which is also in agreement with the increase of river discharge into the bay of Guayaquil (Fig. 4). Therefore we infer changes in sea levels that controlled the expansion of the mangrove on the coast and a weak influence of the ITCZ that prevented the expansion of the Andean forest on the flanks of the western cordillera during this interval. From 4200 to 2850 cal yr BP the contraction of Alnus-dominated woodlands contemporaneously with the reduction of Andean forest and mangrove characterize cooler and drier climatic conditions on the continent. Both the expansion of the coastal desert herbs, and particularly high-salinity tolerant plants such as Chenopodiaceae, and the cooler SSTs suggest a more northernmost influence of the Humboldt Current than today. The weak river discharges attest of low moisture rates on the continent. The influence of the ITCZ was still weak or absent and seasonal rainfalls were was reduced.

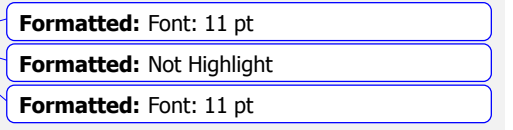

Formatted: Font: $11 \mathrm{pt}$, Not Italic

Formatted: Font: $11 \mathrm{pt}$, Not Italic

Formatted: Font: $11 \mathrm{pt}$ 
After 2850 cal yr BP the re-expansion of the Andean alders and of the mangrove swamp characterizes the return to warmer conditions on land. After a short cooling, SSTs also exhibit a warming trend. The Andean forest long-term decreasing decrease trend $\sim$ from $\simeq 2850$ up to $1850 \mathrm{cal}$ yr BP can be explained by low elevation cloud formation due to a weak land-sea temperature contrast. This trend reversed during the last two millennia as thatwhich were marked by a rainfall increased. The last 2850 cal yr BP was also punctuated by a high frequency and amplitude of contraction/expansion of different ecosystems, Andean forest, mangrove or coastal desert, with three alternated 16

phases of major expansion - regression of the Andean forest versus coastal herbsvegetation. Therefore, $₹$ The

observed increase in of Alnus frequencies-woodlands in the forestover the last two millennia could also be ${ }_{-}$ however, also-explained by agroforestry as demonstrated in an Andean archeological site (Chepstow-Lusty et al., 2000).

\section{2- Orbitally-driven climatic variability in the Guayaquil region.}

The last 12,000 years are characterized by three steps in the amount of insolation (Fig. 4). The first step shows maxima in the Northern Hemisphere $(\mathrm{NH})$ boreatsummer insolation and minima in Southern Hemisphere (SH) summer austral winterinsolation. The second step is a progressive increase of the insolation values in the $\mathrm{SH}$ with the associated progressive decrease in the $\mathrm{NH}$. The third step is the reverse situation when comparing with the early Holocene.

In the early Holocene the maximum summer insolation at $65^{\circ}$ variations in the $\mathrm{NH}$ mid and high latitudes (Berger et al., 1978), and the progressive sea level rise associated with the last deglaciation, ended at $\sim 7000 \mathrm{cal}$ yr BP. Between the early and late Holocene the progressive decrease/increase of insolation values in the $\mathrm{NH} / \mathrm{SH}$ is well reflected in the global trends of vegetation development with, for instance, the progressive decrease of Andean forests and mangroves and the increase of coastal herbs. However superimposed to this orbital forcing, variability in the SSTs and the mean position of the ITCZ bring some local effects in the climate and environmental features of the continent such as the extremely-dry event observed between 4200 and 2850 cal yr BP.

Our data indicate that long-term changes of the Andean forest cover were controlled by insolation variations at $65^{\circ} \mathrm{N}$ affecting the ITCZ position and related precipitation. The period between 4200 and 2850 cal yr BP coincides with low boreal summer insolation but high summer insolation at $3^{\circ} \mathrm{S}$, and shows a minimum development of Andean forest, mangrove and Alnus synchronous with an optimal development of coastal herbs and slightly lower SSTs. Insolation 
forcing drives the temperature gradients between low and high latitudes and consequently the position of the ITCZ. A southern migration of the ITCZ should induce a rainfall increase in the Guayaquil basin. However, we observe the driest conditions of the Holocene suggesting that the ITCZ was located further north, somewhere between $1^{\circ} \mathrm{S}$ and $3^{\circ} \mathrm{S}$ where high moisture rates are observed (Lim et al 2014). This period, 4,200-2,850 cal yr BP, also coincides with weaker ENSO frequency compared to the last $2000 \mathrm{yr}$ (Moy et al 2002).

The third long-term phase, since 2,850 cal yr BP up to the present, is characterized by progressive, but irregular, increases in both SSTs and river discharge (terrigenous material) that followed the same trend than the austrat $\underline{\mathrm{SH}}$ wintersummer insolation. Annual rainfall distribution responds to the southward ITCZ shifts that reached the latitude of Guayaquil and adopted the same bimodal seasonality than today (Fig. 1). However Andean forest, coastal herbs and mangrove do not follow the orbital trend and show high variability with an opposite pattern between, on the one hand, mangrove and Andean forest expansion and, coastal herbs regression on the other hand.

\section{3- Millennial scale variability in the Guayaquil basin}

Superimposed to the orbitally-driven climate variability, a succession of millennial-scale warm-wet/cool- dry intervals are recorded in the region of Guayaquil. Most of the regional forest cover contractions, indicating cooling/drying events are contemporaneous with SST decreases that are weak, but larger than the error of the alkenone method $\left(0.4^{\circ} \mathrm{C}\right)$ (Pailler and Bard, 2002). We observe that the weak and low frequency ENSO events identified between 12,000 and 5,000 cal yr BP (Moy et al., 2002; Liu et al., 2014) coincide with muted Andean forest contraction/expansion in the Guayaquil basin (Fig. 5). We also observe that the high variability and amplitude of the Andean forest changes is observed when ENSO frequency and amplitude increased, i.e. during the last 3000 years (Fig. 5). Based on Andean forest changes, a major increase of precipitation in the Bay of Guayaquil occurred at $\sim 3,000,2,000$ and 1,200 cal yr BP which coincides with precipitation increase observed recorded at the Galapagos lake El Junco (Conroy et al., 2008). On the other hand, the coolest events observed at 2,500, 1,500 and 1,000 cal yr BP in the Guayas Grayauil-basin are contemporaneous with cooling in the Bay of Guayaquuil and could be related to a further northward penetration of the Humboldt Current along the coast of Peru. Therefore we infer abrupt changes in the upwelling system driven either by the Humboldt Current or by ENSO at multidecadal scales, or both, for the last millennia, thus reinforcing (or weakening) the average ITCZ-forced high (low) precipitations in the GuayaquitGuayas basin. 
Figure 5

41R0

11

4132

\subsection{The last 1000 years}

During the last 1000 years the re-expansion of the glaciers $\theta$ fduring the Little Ice Age (LIA) isis associated with three dry phases interrupted by two wet phases astan Ecuadorian Andes; the phase is bracketed by trier ones-(Reuter et al 2009; Ledru et al 2013). During this interval, we also observed in the cortern CordilleraWestern Cordillera five changes in the development of Andean forest (Fig. 6). Forest contraction, $400-300$ cal yr BP, is inferred in the middle of the LIA bracketed by two periods of higher Andean forest cover indicating a one century dry event mimicking the climatic evolution already inferred from regional speleothem and other pollen records. These five intervals are also observed in the pollen record of Papallacta $\left(00^{\circ} 21^{\prime} 30 \mathrm{~S} ; 78^{\circ} 11^{\prime} 37 \mathrm{~W}\right.$ at an elevation of $3815 \mathrm{~m}$ asl). They reflect changes in the Pacific Ocean SST and ITCZ shifts on both sides of the Andean Cordillera. Between 1000 and 750 cal yr BP the dry environment is related to low SST and low terrigenous deposits in the Bay of Guayaquil. At Cascayunga (Reuter et al., 2009) the moisture rates decrease showing that our records are in-phase and may display a regional climate trend. This interval reflects cold and dry climatic conditions during a high interdecadal ENSO variability and a northern position of the ITCZ that reduced the amount of rainfalls at the latitude of Guayaquil.

Figure 6

Between 750 and $450 \mathrm{cal}$ yr BP the high terrigenous are in phase with the high moisture rates showed shown the speleothem record in Cascayunga (Reuter et al., 2009). However the Andean forest was not well developed during this interval and we rather infer a melting phase of the glacier at high elevation in phase with the high SST than higher precipitation rates on the western CordilleraWestern Cordillera. Our pollen record also shows a development in the desertic environment related to the strength of the Humboldt Current that could be related to the low interdecadal ENSO variability at low latitudes.

Between 450 and $350 \mathrm{cal}$ yr BP the SSTs are decreasing and the terrigenous input is low reflecting cold and wet climatic conditions with a progressive drying trend along this interval. The ITCZ is reaching the latitude of Guayaquil
Formatted: Font: $11 \mathrm{pt}$

Formatted: Font: $11 \mathrm{pt}$ 
at the beginning of the interval and progressively moving northward as attested by the following interval, $-b$. Between 350 and $250 \mathrm{cal}$ yr BP where the vegetation, the low SST and the low terrigenous input tharacterizereflect the presence of stronger Humboldt Current, the absence of the and a weak influence of the ITCZ under low interdecadal ENSO variability. During this interval the moisture rates were lower than in the previous phase on both sides of the Cordillera. This interval characterized the Little Ice Age in the Ecuadorian Andes (Ledru et al 2013). After 250 cal yr BP the SST increase and the composition of the vegetation reflects the installation of a warm and wet climate on the continent. The moisture rates observed at Guayaquil are out of phase with the speleothem record of Cascayunga as were those of Papallacta on the eastern CordilleraEastern Cordillera. A different origin for moisture, such as cloud dripping and upslope convective activity, was inferred at Papallacta to explain these differences between groundwater level (speleothem) and development of a wet rainforest on the slopes of the Cordillera (pollen records).

\section{6-Conclusions}

Our marine record is well connected with the orbitally-driven and SST-controlled climate changes of the tropical Andes (Jomelli et al 2011; Polissar et al 2013). Moreover we assess the responses of the vegetation to these forcings and their associated ocean-atmosphere couplings on the equatorial Pacific coast and on the Wwestern $\underline{C} \in$ cordillera. We confirm that marine pollen records collected from the river outlets accurately-represent an integrated image of the regional vegetation of the adjacent landmasses and, consequently, the climatic parameters under which this vegetation developed. We show that changes in insolation, SSTs and ITCZ control the hydrological cycle in this area. Derived changes in the seasonality, in the strength of the Humboldt Current activity and in multi decadal scale ENSO variability show three main phases of ocean-atmosphere coupling during a continuous increase/decrease trend of southernaustral wintef/northern-boreal summer hemisphere insolation. These three climatic phases are associated to specific vegetation assemblages on the continent and more specifically on the Western Cordillera. During the early to middle Holocene, between 11,700 and $7700 \mathrm{cal} \mathrm{yr} \mathrm{BP,} \mathrm{climate} \mathrm{conditions} \mathrm{in} \mathrm{the} \mathrm{Guayaquit} \mathrm{Guayas} \mathrm{basin} \mathrm{were}$ controlled by the position of the ITCZ. The ITCZ was located further north and southern/northern hemisphere-austral bboreal summer insolation was at a minimum/maximum. Rainfalls were scarcePrecipitation was low but clouds formed on the cortern Cordillerawestern Cordillera due to a warm land-cold sea thermal contrast while glaciers were rapidly melting in the Andes. This dry period coincides with simulated relatively weak ENSO strength. The progressive increase of SSTsinduced, along the sea level rise, induced the full development of the mangrove in the
Formatted: Not Highlight Formatted: Font: $11 \mathrm{pt}$
Formatted: Font: $11 \mathrm{pt}$

Formatted: Font: $11 \mathrm{pt}$

Formatted: Not Highlight

Formatted: Font: $11 \mathrm{pt}$ 
Bay of Guayaquil. In the second phase, $7700-2850$ cal yr BP, the SSTs reached a maximum and showed high variability between two extreme cold events (at $\sim 4,500$ and 3,500 cal yr BP) and one extreme warm event ( 4000 cal yr BP). 9

The progressive southward shift of the mean position of the ITCZ had not yet reached the latitude of Guayaquil and 11

CordilleraWestern Cordillera while Alnus became more abundant. The simultaneous regression of the mangrove and

(Braconnot et al 2011), mainly related to the absence of the seasonal shift of the ITCZ under at this latitude as the SSTs remained high and ENSO variability was low. The short interval between 4200 and 2850 cal yr BP shows the

coolest and driest climatic conditions of the Holocene and a northward shift of the Humboldt Current influence are

inferred together with a northern position of the ITCZ. In the third phase, between $2850 \underline{\mathrm{cal} \text { yr BP }}$ and today, a high

variability in the land-sea connections likely related with the high variability in frequency and strength of ENSO is documented by successive large expansion and contraction phases of the tropical forest and coastal herbs. Pacific

\section{Acknowledgements}

This research is a contribution of Sonderforschungsbereich 754 Climate-Biogeochemistry interactions in the tropical ocean (http://www.sfb754.de) ${ }_{L}$ which is supported by the Deutsche Forschungsgemeinschaft) and to the projectof the French Research Agency ANR 2010 BLANC 608-01 ELPASO (MPL) project. We thank Henry Hooghiemstra and an anonymous referee for their insightful comments on the original manuscript.

\section{References}


Barthlott, W., Mutke, J. Rafiqpoor, M. D., Kier, G. and Kreft. H. 2005. Global centres of vascular plant diversity. Nova Acta Leopoldina 92, 61-83.

Berger, A. 1978. Long-term variations of daily insolation and quaternary Quaternary climatic changes. Journal of Atmospheric Science 35, 2362-2367.

Bond, G., Kromer, B., Beer, J., Muscheler, R., Evans, M., Showers, W., Hoffmann, S., Lotti-Bond, R., Hajdas, I. and Bonani, G. 2001. Ppersistent solar influence on North Atlantic climate during the Holocene. Science 294, 2130-2136. Braconnot, P., Luan, Y., Brewer, S., Zheng, W. 2012. Impact of Earth's orbit and freshwater fluxes on Holocene climate mean seasonal cycle and ENSO characteristics. Climate Dynamics 38, 1081-1092.

Cane, M. 1983. Oceanographic events during El Niño. Science 222, 1189-1195.

Carré, M., Azzoug, M., Bentaleb, I., Chase, B.M., Fontugne, M., Jackson, D., Ledru, M.-P., Maldonado, A., Sachs, J.P. and Schauer, A.J. 2012. Mid-Holocene mean climate in the south-eastern Pacific and its influence on South America. Quaternary International 253, 55-66.

Chepstow-Lusty, A. and Winfield, M. 2000. Inca agroforestry: lessons from the past. Ambio 29, 322-328

Clément, A.C., Seager, R., Cane, M.A. 2000. Suppression of El Niño during the mid-Holocene by changes in the Earth's orbit. Paleoceanography, 15, 731-737.

Colinvaux, P. A., Bush, M.B., Steinitz-Kannac, M., Millerd, M. C. 1997. Glacial and postglacial pollen records from the Ecuadorian Andes and Amazon. Quaternary Research 48, 69-78.

Conroy, J L., Overpeck, J. T., Cole, J. E., Shanahan, T. M., Steinitz-Kannan, M. 2008. Holocene changes in eastern tropical Pacific climate inferred from a Galápagos lake sediment record. Quaternary Science Rfeviews 27, 1166-1180. Dupont, L. M. and Wyputta, U. 2003. Reconstructing pathways of aeolian pollen transport to the marine sediments along the coastline of SW Africa. Quaternary Science Reviews 22, 157-174.

Ellison, J.C. and Stoddart., D.R. 1991. Mangrove retreat with rising sea-level. Journal of Coastal Research 7, 151-165.

Garreaud, R. D., Vuille, M.,_Compagnucci, R., andMarengo, J. 2009. Present-day South American climate,

González, C., Urrego, L.E and Martínez, J.I. 2006. Late Quaternary vegetation and climate change in the Panamá Basin: Palynological evidence from marine cores ODP 677B and TR 163-38. Palaeogeography, Palaeoclimatology, Palaeoecology 234, 62-80. 
Haug, G.H., Hughen, K.A., Sigman, D.M., Peterson, L.C., Röhl, U._2001. Southward migration of the intertropical convergence zone through the Holocene. Science 293, 1304-1308.

Heusser, L.E., Balsam, W.L. 1977. Pollen distribution in the N.E. Pacific Ocean. Quaternary Research 7, 45-62. Heusser, L. 1985. Quaternary palynology of marine sediments in the northeast Pacific, northwest Atlantic, and Gulf of Mexico. In: Pollen records of Late-Quaternary North American sediments, American Association of Stratigraphic Palynologist, 385-403.

Hooghiemstra, H., 1984. Vegetational and climatic history of the high plain of Bogotáz', Colombia. Dissertationes Botanicae 79, 1-368.

Hooghiemstra, H., Lézine, A.-M., Leroy, S.A.G., Dupont, L., Marret, F. 2006. Late Quaternary palynology in marine sediments: a synthesis of the understanding of pollen distribution patterns in the NW African setting. Quaternary International $148,29-44$. Jomelli, V..,Khodri, M., Favier, V., Brunstein, D., Ledru, M.-P.,Wagnon, P., Blard, P.-H., Sicart, J.-E., Braucher, R., Grancher, D., Bourlès, D. L., Braconnot, P., Vuille, M. 2011. Irregular tropical glacier retreat over the Holocene epoch driven by progressive warming. Nature 474, 196-199.

Jomelliet al 2011

Jorgensen, P. M. and Leon-Yanez, S. 1999. Catalogue of the vascular plants of Ecuador. Missouri Botanical Garden, Saint Louis, Missouri, USA.

Juggins, S., 2009. Package "rioja" - Analysis of Quaternary Science Data, The Comprehensive R Archive Network. Lambeck, K. and Chappell, J. 2001. Sea level Change through the last Glacial Cycle. Science 292, 679-685. Ledru, M.P., Jomelli, V., Samaniego, P., Vuille, M., Hidalgo, S., Herrera, M. and Ceron, C. 2013. The Medieval Climate Anomaly and the Little Ice Age in the Eastern Ecuadorian Andes. Climate of the Past 9, 307-321.

Leduc, G., Vidal, L., Tachikawa, K., and-Bard, E. 2009. ITCZ rather than ENSO signature for abrupt climate changes across the tropical Pacific? Quaternary Research 72, 123-131,

Lim, S., Ledru, M.-P., Bremond L., Valdez F., Devillers, B. Hougnon, A., Favier, C. 2014. Ecological effects of natural hazards and human activities on the Ecuadorian Pacific coast during the late Holocene. Palaeogeography,

Palaeoclimatology, Palaeoecology 415, 197-209.

Liu, Z., Lu, Z., Wen, X., Otto-Bliesner, B. L., Timmermann, A.,Cobb, K. M. 2014. Evolution and forcing mechanisms of El Niño over the past 21,000 years. Nature $515,550-553$.
Formatted: Font: +Body (Calibri), $11 \mathrm{pt}$ Formatted: Don't adjust space between Latin and Asian text, Don't adjust space between Asian text and numbers

Formatted: Font: $11 \mathrm{pt}$, Italic

Formatted: Font: +Body (Calibri), $11 \mathrm{pt}$, English (U.S.)

Formatted: Font: +Body (Calibri), 11 pt, English (U.S.)

Formatted: Font: +Body (Calibri), $11 \mathrm{pt}$, English (U.S.)

Formatted: Font: +Body (Calibri), 11 pt, English (U.S.)

Formatted: Font: +Body (Calibri), $11 \mathrm{pt}$ English (U.S.)

Formatted: Don't adjust space between Latin and Asian text, Don't adjust space between Asian text and numbers

Formatted: Font: +Body (Calibri), 11 pt, English (U.S.)

Formatted: Font: +Body (Calibri), 11 pt, Italic, English (U.S.)

Formatted

Formatted: Font color: Black

Formatted: Font: +Body (Calibri), 11 pt

Formatted: Font: +Body (Calibri), $11 \mathrm{pt}$

Formatted: French (France)

Formatted: Font: +Body (Calibri), $11 \mathrm{pt}$

Formatted: Font: +Body (Calibri), 11 pt

Formatted: Font: +Body (Calibri), 11 pt

Formatted: Font: +Body (Calibri), $11 \mathrm{pt}$

Formatted: Font: +Body (Calibri), 11 pt

Formatted: Font: +Body (Calibri), 11 pt

Formatted: Font: +Body (Calibri), 11 pt

Formatted: Font: +Body (Calibri), 11 pt

Formatted: Font: +Body (Calibri), 11 pt

Formatted: Font: +Body (Calibri), 11 pt

Formatted: Font: +Body (Calibri), 11 pt

Formatted: Font: +Body (Calibri), 11 pt

Formatted: Font: +Body (Calibri), 11 pt

Formatted

Formatted: Font: +Body (Calibri), $11 \mathrm{pt}$

Formatted: Font: +Body (Calibri), 11 pt

Formatted: Font: +Body (Calibri), $11 \mathrm{pt}$

Formatted: Font: +Body (Calibri), $11 \mathrm{pt}$

Formatted: Font: +Body (Calibri), 11 pt

Formatted: Font: +Body (Calibri), 11 pt

Formatted: Font: +Body (Calibri), 11 pt

Formatted: Font: +Body (Calibri), 11 pt

Formatted: Font: +Body (Calibri), 11 pt

Formatted: Font: Italic

Formatted 
Marchant, R., Almeida, L. Behling, H., Berrio, J.C., Bush, M., Cleef, A., Duivenvoorden, J., Kappelle, M., De Oliveira, P., $\underline{\text { Teixeira de Oliveira-Filho, A., Lozano-García, S, Hooghiemstra, H., Ledru, M-P., Ludlow-Wiechers, B., Markgraf, V., }}$

Mancini, V., Paez, M., Prieto, A., Rangel, O., Salgado-Labouriau, M.L. 2002. Distribution and ecology of parent taxa of pollen lodged within the Latin American Pollen Database. Review. Paleobotany and Palynology 121, 1-75.

Mollier-Vogel, E., Leduc, G., Böschen, T., Schneider, R. R. 2013. Rainfall response to orbital and millennial forcing in northern Perú over the last 18 ka. Quaternary Science Reviews 8, 125-141.

Morales, M. S., Christie, D. A., Villalba, R., Argollo, J., Pacajes, J., Silva, J. S., Alvarez, C. A., Llancabure, J. C., Soliz Gamboa, C. C. 2012. Precipitation changes in the South American Altiplano since 1300 AD reconstructed by treerings. Climate of the Past 2, 653-666.

Mourguiart, P. and Ledru, M.-P. 2003. Last glacial maximum in an Andean cloud forest environment (Eastern Cordillera, Bolivia). Geology 31, p.195-198

Moy, C.M., Seltzer, G.O., Rodbell, G.T. and Anderson, D.M. 2002. Variability of El Niño/Southern Oscillation activity at millennial timescales during the Holocene epoch. Nature 420, 162-165.

Pailler, D. and Bard, E. 2002. High frequency palaeoceanographic changes during the past 140,000 yr recorded by the organic matter in sediments of the Iberian margin. Palaeogeography, Palaeoeclimatology, Palaeoecology 2799, 1-22. Parkinson, R. W., Delaune, R. D., White, R. J. 1994. Holocene sea-level and the fate of Aangrove-mangrove fForests within the wider Carribean region. Journal of Coastal Research 10, 1077-1086.

Reimer, P.J., Baillie, M. G. L., Bard, E., Bayliss, A., Beck, J. W., Blackxell, P. G., Ramsey, C. B., Buck, C. E., Burr, G. S., Edward, R. L., Friedrich, M., Grootes, P. M., Guilderson, T. P., Hajdas, I., Heaton, T. I., Hagg, A. G., Hughen, K. A., Kaiser, K. F., Kromer, B., McCormac, F. G., Manning, S. W., Richards, D. A., Southon, J. R., Talamo, S., Turney, C. S. M., Van der Plicht, J. and Weyhenmeyer, C. E. 2009. IntCal09 and Marine09 radiocarbon age calibration curves, 50,000 years cal BP. Radiocarbon 51, 11111150.

Reuter, J., Stott, L., Khider, D., Sinha, A., Cheng, H., and Edwards, R. L. 2009. A new perspective on the hydroclimate variability in northern South America during the Little Ice Age. Geophysical Research Letters 36, L21706.

Rincón-Martínez, D., Lamy, F., Contreras, S., Leduc,G., Bard, E. , Saukel, C., Blanz, T., Mackensen, A. and Tiedemann, R. 2010. More humid interglacials in Ecuador during the past 500 kyr linked to latitudinal shifts of the equatorial front and the Intertropical Convergence Zone in the eastern tropical Pacific. Paleoceanography 25, PA2210. 

from the Galápagos Islands. Journal of Paleolimnology 27, 1-7.

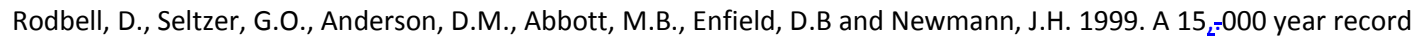
11 of El Niño driven alluviation in southwestern Ecuador. Science 283, 516-520.

Roubik, D.W. and Moreno, E. 1991. Pollen and Spores of Barro Colorado Island.:-Monographs in Systematic Botany, 36. Missouri Botanical Garden, St Louis, MO.

Siddall, M., Rohling, E. J., Almogi-Labin, A., Hemleben, Ch., Meischner, D., Schmelzer, I. and Smeed, D. A. 2003. Sealevel fluctuations during the last glacial cycle. Nature 423, 853-858.

Stevenson, M. R. 1981. Seasonal variations in the Gulf of Guayaquil, a tropical estuary. Boletin Cientifico y Técnico, Instituto Nacional de Pesca 4, 1-133.

Troll, C. 1968. Geoecologia de las regions montañosas de las Américas tropicales, 223p. Colloquium Geographicum, vol. 9 Ferd, Dummlers 마erleag, Bonn: Unesce, Germany.

Tudhope, A.W., Chilcott, C.P., McCulloch, M.T., Cook, E.R., Chapell, J., Ellam, R.M., Lea, D.W., Lough, J.M. and Shimmeld, G.B. 2001. Variability in the El Nino-Southern Oscillation through a glacial-Interglacial Cycle. Science 291, 1511-1517.

Twilley, R.R., Cárdenas, W., Rivera-Monroy, V.H., Espinoza, J., Suescum, R., Armijos, M.M. and Solórzano, L. 2001. The Gulf of Guayaquil and the Guayas River estuary, Ecuador. In Seelinger, U., Kjerfve, B. (Eds.), Coastal Marine Ecosystems in Latin America. Ecological Studies 144, 245-264.

Urrego, D. H., Silman, M. R., Correa-Metrio, A., and Bush, M. B. 2011. Pollen-vegetation relationships along steep climatic gradients in western Amazonia. Journal of Vegetation Science 22, 795-806, 10.1111/j.1654

\subsubsection{9.x}

Vuille, M., Bradley, R.S. and Keimig, F. 2000. Climate Variability variability in the Andes of Ecuador and lts-its

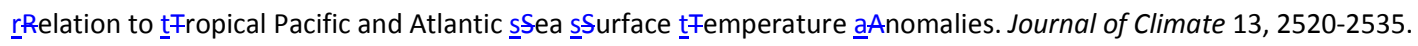
Vuille, M., Franquist, E., Garreaud R. Lavado Casimiro, W.S., and Cáceres, B. 2015. Impact of the global warming hiatus on Andean températuretemperature.Journal of Geophysical Research, DOI 10.1002/2015JD023126.

Weng, C., Bush, M. B. and Cheptow-Lusty, A. J. 2004. Holocene changes of Andean alder (Alnus acuminata) in highland Ecuador and Peru. Journal of Quaternary Science 19, 685-691.
Formatted: English (U.S.)

Formatted: English (U.S.)

Formatted: Font: +Body (Calibri), $11 \mathrm{pt,}$ English (U.S.)

Formatted: English (U.S.)

Formatted: Font: +Body (Calibri), $11 \mathrm{pt,}$ English (U.S.)

Formatted: English (U.S.)

Formatted: No widow/orphan control, Don't adjust space between Latin and Asian text, Don't adjust space between Asian text and numbers

Formatted: English (U.S.)

Formatted: Font: +Body (Calibri), $11 \mathrm{pt,}$ English (U.S.)

Formatted: Font: +Body (Calibri), $11 \mathrm{pt}$, English (U.S.)

Formatted: English (U.S.)

Formatted: Font: +Body (Calibri), $11 \mathrm{pt}$, English (U.S.)

Formatted: English (U.S.)

Formatted: Font: +Body (Calibri), $11 \mathrm{pt}$, English (U.S.)

Formatted: Font: +Body (Calibri), $11 \mathrm{pt}$, English (U.S.)

Formatted: Font: Italic, English (U.S.)

Formatted: Font: +Body (Calibri), $11 \mathrm{pt}$, English (U.S.)

Formatted: Font color: Custom Color(RGB(10,58,105)) 
Witt, C.S. and Bourgois, J. 2010. Forearc basin formation in the tectonic wake of a collision-driven, coastwise migrating crustal block: the example of the North Andean block and the extensional Gulf of Guayaquil-Tumbes Basin (Ecuador-Peru border area). Geological Society of America Bulletin 122, 89-108.

Wyrtki, K. 1975. EL Niño-The dynamic response of the equatorial Pacific Ocean to atmospheric forcing. Journal of Physical and Oceanography 5, 572-584.

\section{Figure and Table captions}

Figure 1 - Map of the Guyaquil basin showing the distribution of the main vegetation types (redrawn from Troll, 1968). Top left a pie diagram showings the pollen assemblage from the core top sample that represents the different pollen percentages (numbers in black) of the vegetation communities (same colors as the map) occupying the Guayas basin during the last decades.

Figure 2 - Pollen percentage diagram with selected taxa of core M772-056. Changes in pollen perentages are Pollen frequencies are represented along a time scaleplotted against age. Dashed black lines indicate the 5 main pollen zones; grey solid lines indicate the pollen sub-zones. Blue and orange background for humid and dry conditions, respectively.

Figure 3 - Alnus pollen frequencies-percentage values along a time scale at Surucucho (Colinvaux et al. 1997) and in core M772-056.

Figure 4 - Direct comparison between SST changes in the Bay of Guyaquil and vegetation-based atmospheric changes in the Guayas basin Environmental changes in the Bay of Guyaquil during the Holocenefrom the analysis of core M772-056: a) Mangrove and coastal vegetation pollen percentage curves with insolation values for both hemisphere (from Berger and Loutre), b) Alnus pollen percentage curve, c) Andean forest pollen percentage curve, d)

Formatted: Font: Italic TI/Caand changes in SSTUK, ${ }_{37}$-based SST changes are represented by Uk37 (from (Mollier-Vogel et al., 2013), e) Log(

$\mathrm{TI} / \mathrm{Ca}$ ) record, and and changes in pollen indicator frequencies, Andean forest, Alnus, coastal herbs, mangrove (this Formatted: Subscript study). F) changes in boreal $\left(65^{\circ} \mathrm{N}\right)$ summer and austral $\left(3^{\circ} \mathrm{S}\right)$ winter summer? insolations (Berger, 1978). Blue and orange background for humid and dry conditions, respectively.

Figure 5 - ENSO variability (from-Moy et al. 2002) and Andean forest pollen frequencies-percentage curve (this study) during the Holocene. 
Figure 6 - Precipitation changes during tThe last 1000 years on the equatoriat Eastern Equatorial Pacific coastal region of South America from the: a) $\delta^{18} O$ speleothem record of Cascayunga (CAS A+D, Reuter et al., 2009), b) Alnus, Mangrove and Coastal vegetation pollen percentage curves from core M772-056, c) Andean forest pollen percentage curve from core M772-056, d) Uk'

Formatted: Subscript orange arrows show wet and dry phases during the tast Little Ice Age (LIA), respectively. Black dashed lines indicate the three hydro-climate intervals based on terrigenous input in the Bay of Guayaquil discussed in the text.

Table I - List of the-identified pollen taxa in marine core M772 056-5 (Guayaquil Basin, Eastern Equatorial Pacific) and clustering into included in the 5 main ecological groups after their main ecological affinityfound in the Holocene sediments of marine core $M 772$ 056-5 (Guayaquil Basin, eastern equatorial Pacific).

Table II- Radiocarbon dates $\left({ }^{14} \mathrm{C}-\mathrm{AMS}\right.$ ) and sample specific data used for the age model of core M772-056 (Mollier-

Formatted: Superscript

Vogel et al., 2013). Radicarbon measurements were performed on the planktonic foraminifera Neogloboquadrina

Formatted: Font: Italic 


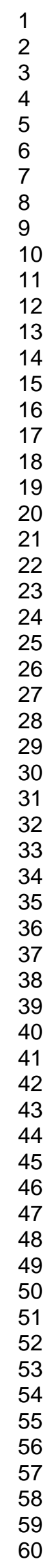

http://mc.manuscriptcentral.com/holocene 


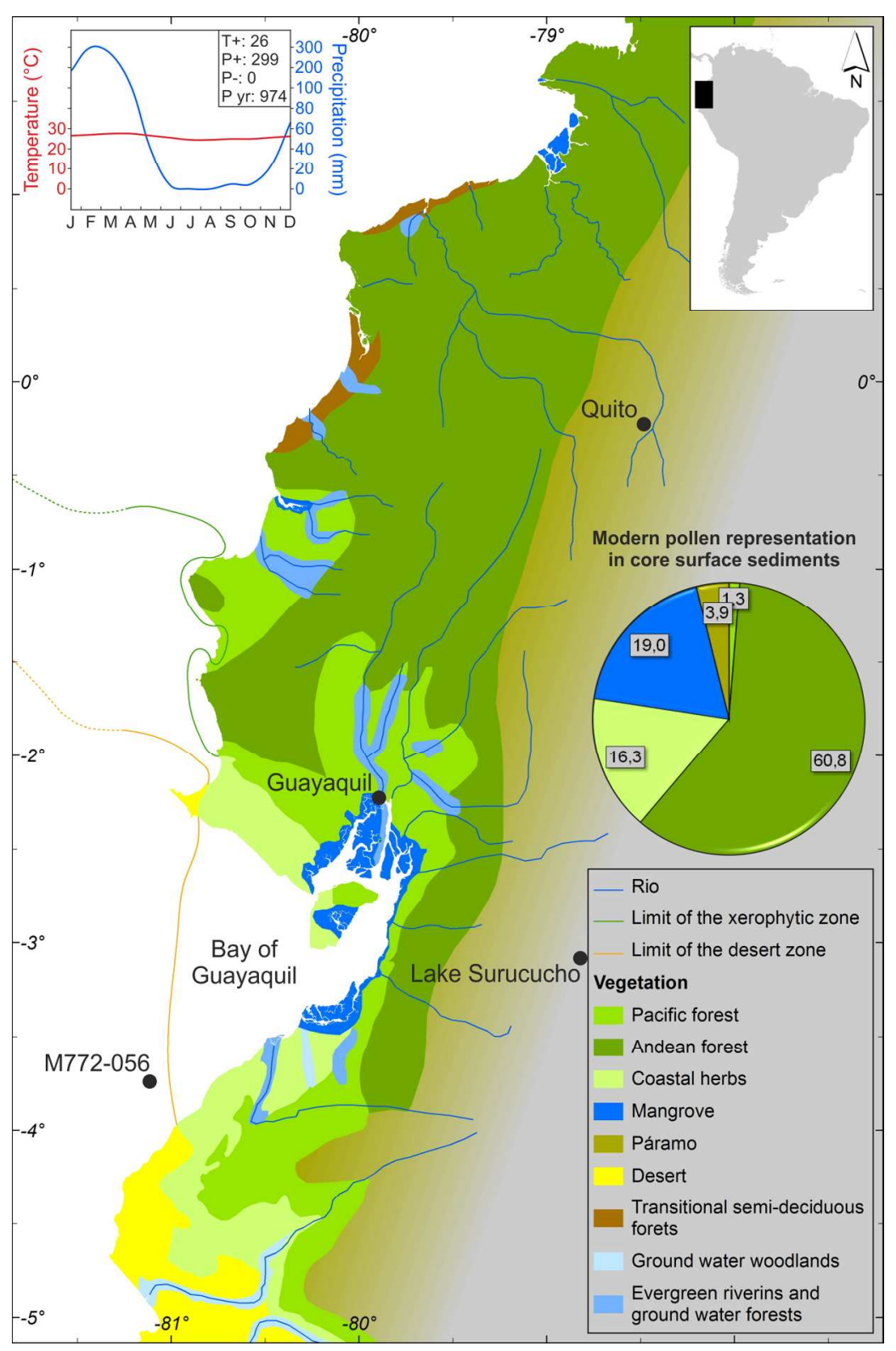

Map of the Guyaquil basin showing the distribution of the main vegetation types (redrawn from Troll, 1968). Top left a pie diagram showing the pollen assemblage from the core top sample that represents the different pollen percentages (numbers in black) of the vegetation communities (same colors as the map) occupying the Guayas basin during the last decades. $141 \times 215 \mathrm{~mm}(299 \times 299$ DPI $)$ 
Pollen percentage diagram with selected taxa of core M772-056. Changes in pollen perentages are plotted against age. Dashed black lines indicate the 5 main pollen zones; grey solid lines indicate the pollen subzones. Blue and orange background for humid and dry conditions, respectively. $263 \times 183 \mathrm{~mm}(300 \times 300 \mathrm{DPI})$ 


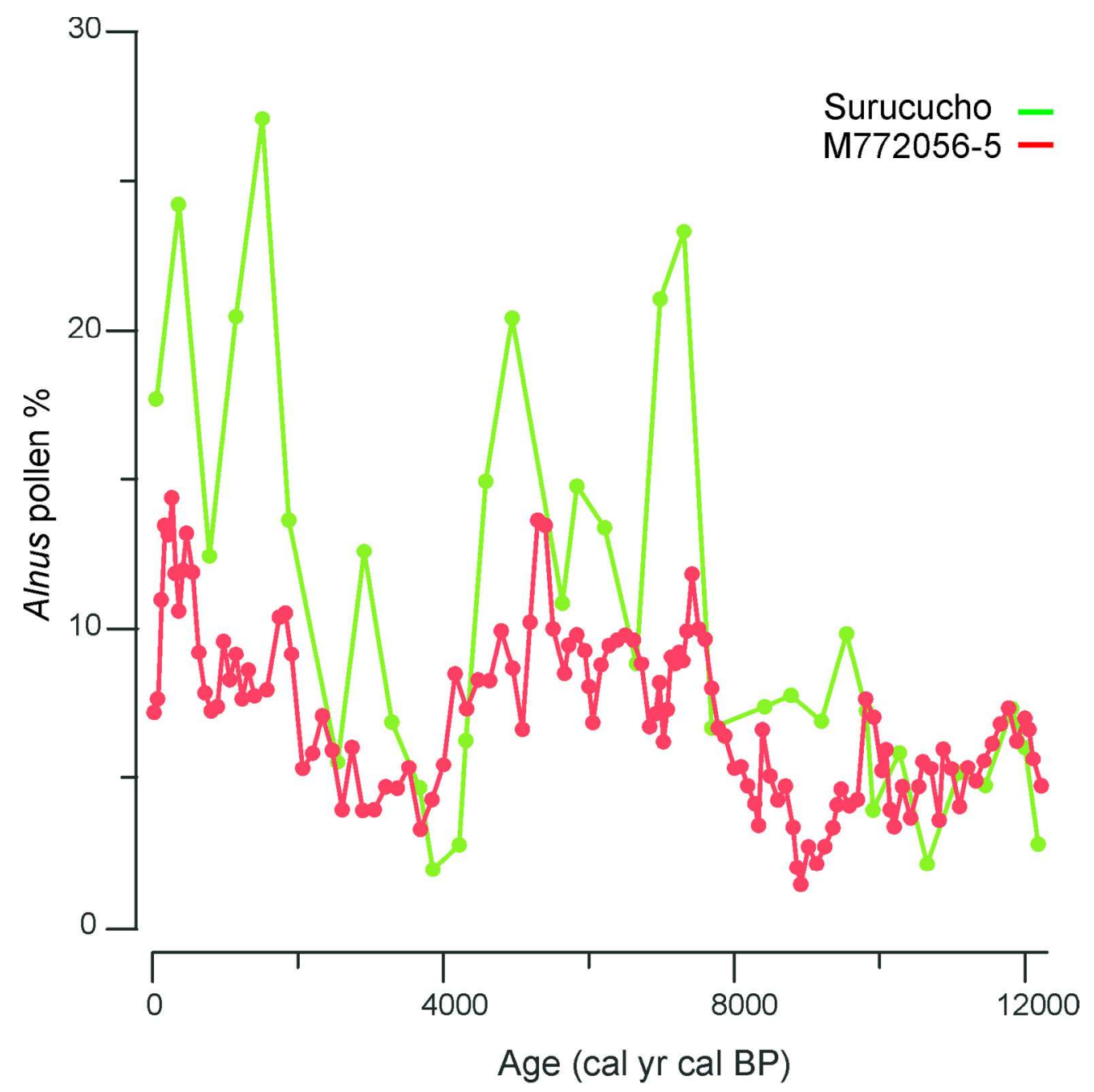

Alnus pollen percentage values along a time scale at Surucucho (Colinvaux et al. 1997) and in core M772056 . $147 \times 148 \mathrm{~mm}(300 \times 300 \mathrm{DPI})$ 


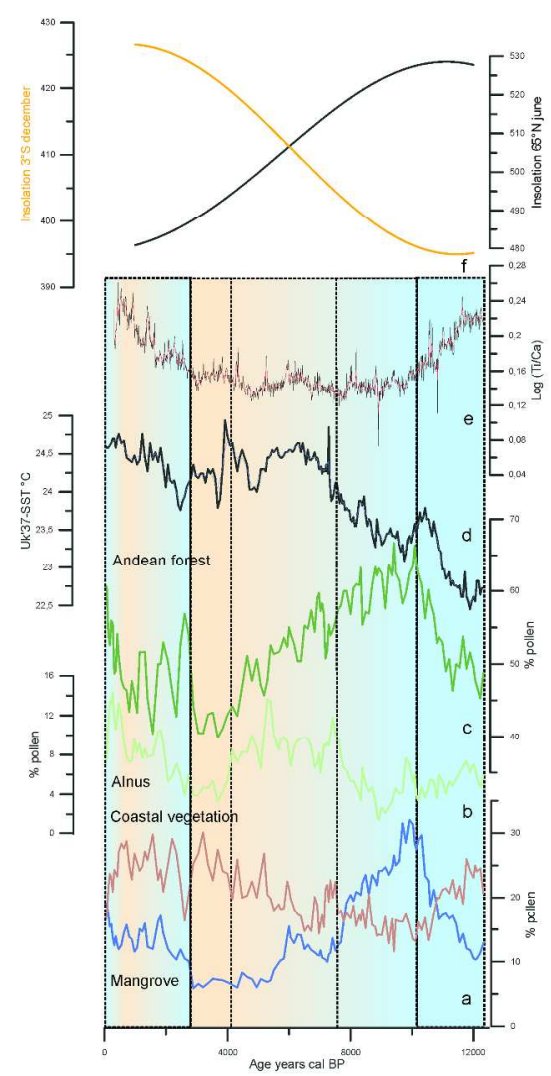

Direct comparison between SST changes in the Bay of Guyaquil and vegetation-based atmospheric changes in the Guayas basin from the analysis of core M772-056: a) Mangrove and coastal vegetation pollen percentage curves, b) Alnus pollen percentage curve, c) Andean forest pollen percentage curve, d) Uk'37based SST changes (Mollier-Vogel et al., 2013), e) Log( TI/Ca) record, and F) boreal $\left(65^{\circ} \mathrm{N}\right)$ summer and austral $\left(3^{\circ} \mathrm{S}\right)$ summer insolations (Berger, 1978). Blue and orange background for humid and dry conditions, respectively.

$217 \times 356 \mathrm{~mm}(300 \times 300 \mathrm{DPI})$ 


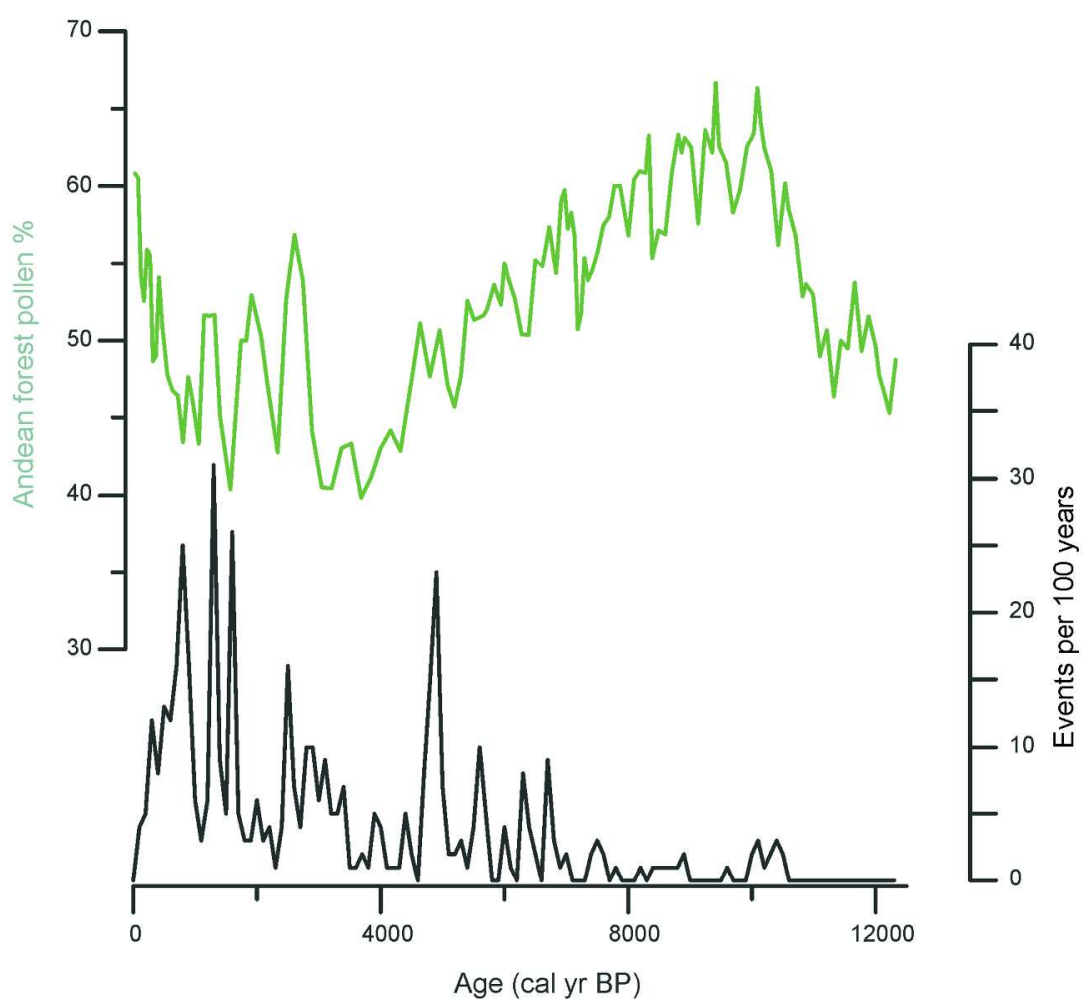

ENSO variability (Moy et al. 2002) and Andean forest pollen percentage curve (this study) during the Holocene. $197 \times 148 \mathrm{~mm}(300 \times 300 \mathrm{DPI})$ 
Precipitation changes during the last 1000 years on the Eastern Equatorial Pacific coastal region : a) $\delta 180$ speleothem record of Cascayunga (CAS A+D, Reuter et al., 2009), b) Alnus, Mangrove and Coastal vegetation pollen percentage curves from core M772-056, c) Andean forest pollen percentage curve from core M772-056, d) Uk'37-based SST from core M772-056, e) [Ti/Ca] curve from core M772-056. Blue and orange arrows show wet and dry phases during the Little Ice Age (LIA), respectively. Black dashed lines indicate the three hydro-climate intervals based on terrigenous input in the Bay of Guayaquil discussed in the text.

$293 \times 338 \mathrm{~mm}(300 \times 300$ DPI $)$ 
Table 1

\begin{tabular}{|c|c|c|c|c|c|}
\hline & Forest & & & Open vegetation & \\
\hline Mangrove & Pacific forest & Andean forest & Páramo & $\begin{array}{c}\text { Coastal herbs \& } \\
\text { shrubs }\end{array}$ & Ubiquists \\
\hline $\begin{array}{l}\text { Rhizophora } \\
\text { Acrostichum }\end{array}$ & $\begin{array}{c}\text { Acanthaceae } \\
\text { Alchornea } \\
\text { Annonaceae } \\
\text { Araceae } \\
\text { Arecaceae-type } \\
\text { Anacardiaceae } \\
\text { Banara-type } \\
\text { Bignoniaceae } \\
\text { Bombacaceae } \\
\text { Bromeliaceae } \\
\text { Burseraceae-type } \\
\text { Cucurbitaceae } \\
\text { Dictyocaryum } \\
\text { Diospyros } \\
\text { Euphorbia/Mabea } \\
\text {-type } \\
\text { Guazuma } \\
\text { Hedyosmum } \\
\text { Hyeronima, } \\
\text { Iriartea } \\
\text { Loranthaceae } \\
\text { Meliaceae } \\
\text { Mimosa } \\
\text { Myrtaceae } \\
\text { Phyllanthus } \\
\text { Rubiaceae } \\
\text { Sapium } \\
\text { Sapotaceae } \\
\text { Sterculiaceae- } \\
\text { type } \\
\text { Ulmaceae } \\
\text { Urticaceae/Morac } \\
\text { eae-type }\end{array}$ & $\begin{array}{c}\text { Alnus } \\
\text { Araliaceae } \\
\text { Bocconia } \\
\text { Bromeliaceae } \\
\text { Caesalpiniaceae } \\
\text { Cerastium/Stellar } \\
\text { ia-type } \\
\text { Clethra } \\
\text { Clusiaceae } \\
\text { Convolvulaceae } \\
\text { Maripa-type } \\
\text { Daphnopsis } \\
\text { Dodonaea } \\
\text { Drimys } \\
\text { Ericaceae } \\
\text { Hedyosmum } \\
\text { Ilex } \\
\text { Juglans } \\
\text { Lamiaceae } \\
\text { Malpighiaceae } \\
\text { Morella (Myrica) } \\
\text { Myrsine } \\
\text { Onagraceae } \\
\text { Passiflora } \\
\text { Polylepis/Acaena- } \\
\text { type } \\
\text { Podocarpus } \\
\text { Proteaceae } \\
\text { Symplocos } \\
\text { Vallea, } \\
\text { Vicia, } \\
\text { Vismia } \\
\text { Weinmannia }\end{array}$ & $\begin{array}{l}\text { Baccharis-type } \\
\text { (Asteraceae } \\
\text { tubuliflorae) } \\
\text { Polylepis/Acaena } \\
\text {-type }\end{array}$ & $\begin{array}{c}\text { Acalypha } \\
\text { Ambrosia-type } \\
\text { Apiaceae Daucus- } \\
\text { type } \\
\text { Bromeliaceae } \\
\text { Campanulaceae } \\
\text { Cerastium/Stellaria- } \\
\text { type } \\
\text { Chenopodiaceae/A } \\
\text { marantaceae-type } \\
\text { Cyperaceae } \\
\text { Ericaceae } \\
\text { Gentianacea } \\
\text { Malvaceae } \\
\text { Plantago } \\
\text { Poaceae } \\
\text { Polygonaceae } \\
\text { Solanaceae } \\
\text { Ranunculaceae } \\
\text { Taraxacum-type } \\
\text { (Asteraceae } \\
\text { liguliflorae) } \\
\text { Thalictrum }\end{array}$ & $\begin{array}{c}\text { Bromeliaceae } \\
\text { Cyperaceae } \\
\text { Fabaceae-type } \\
\text { Hedyosmum } \\
\text { Melastomataceae } \\
\text { Poaceae } \\
\text { Scrophulariaceae }\end{array}$ \\
\hline
\end{tabular}


Table 2- Radiocarbon dates $\left({ }^{14} \mathrm{C}-\mathrm{AMS}\right)$ and sample specific data used for the age model of core M772056 (Mollier-Vogel et al., 2013).

\begin{tabular}{|c|c|c|c|c|}
\hline $\begin{array}{c}\text { Depth } \\
(\mathrm{cm})\end{array}$ & Sample material & $\begin{array}{c}\text { Radiocarbon } \\
\text { age } \\
\left({ }^{14} \mathrm{C} \text { yr BP }\right)\end{array}$ & $\begin{array}{c}\text { Age range (cal } \\
\text { yr BP, } \sigma)\end{array}$ & $\begin{array}{c}\text { Age (cal yr BP mean } \\
\text { value) }\end{array}$ \\
\hline 2 & $\begin{array}{c}\text { Neogloboquadrina } \\
\text { dutertrei }\end{array}$ & 0 & 0 & 0 \\
\hline 49 & N. dutertrei & $1085 \pm 25$ & $416-616$ & 2001 \\
\hline 138 & N. dutertrei & $2575 \pm 30$ & $1850-2153$ & 2841 \\
\hline 199 & N. dutertrei & $3255 \pm 25$ & $2717-2965$ & 5037 \\
\hline 338 & $N$. dutertrei & $4960 \pm 30$ & $4850-5225$ & 5708 \\
\hline 399 & $N$. dutertrei & $5510 \pm 40$ & $5563-5853$ & 6911 \\
\hline 508 & $N$. dutertrei & $6620 \pm 35$ & $6735-7088$ & 7700 \\
\hline 599 & $N$. dutertrei & $7430 \pm 35$ & $7574-7826$ & 8502 \\
\hline 693 & $N$. dutertrei & $8220 \pm 60$ & $8326-8678$ & 12,306 \\
\hline 769 & $N$. dutertrei & $8960 \pm 45$ & $9271-9538$ & 9404 \\
\hline 893 & $N$. dutertrei & $10,085 \pm 45$ & $10,596-11,060$ & 10,828 \\
\hline 999 & $N$. dutertrei & $11,030 \pm 50$ & $12,052-12,561$ & \\
\hline
\end{tabular}

http://mc.manuscriptcentral.com/holocene 
1

2

3

4

5

6

7

8

9

10

11

12

13

14

15

16

17

18

19

20

21

22

23

24

25

26

27

28

29

30

31

32

33

34

35

36

37

38

39

40

41

42

43

44

45

46

47

48

49

50

51

52

53

54

55

56

57

58

59

60

http://mc.manuscriptcentral.com/holocene 